\title{
The Subject of Turkish Higher Education Research: The Case of Faculty Members
}

\section{Türk Yükseköğretim Araştırmalarının Öznesi: Öğretim Üyeleri Örneği}

\author{
Murat ÖZDEMiR, Figen KARAFERYE, Ahmet AYPAY
}

\begin{abstract}
The purpose of this study is to examine the research on faculty members as one of the central subjects of Turkish higher education research based on data from 256 articles, master's and doctoral theses between 2015 and 2019. An analytical framework was used to review and classify the information on research and researchers, the object of study, and the object of knowledge. Turkish higher education research on faculty members was mainly published in the form of articles in peer-reviewed journals in Turkish. The primary objects of study were about the islands of teaching and learning, policy studies, identity development, institutional research, and the scholarships of discovery and teaching. As for the object of knowledge, Turkish higher education research on faculty members was found to be descriptive. Quantitative studies employed parametric tests for research data based on the target population and simple random sampling with a maximum of 400 respondents. The qualitative studies used interviews and content analysis for data collection and analysis. Establishing structures focusing on systematic and long-term research on faculty around the issues such as recruitment, career, and post-career stages was among the recommendations of the paper.
\end{abstract}

Keywords: Faculty members, Researchers, The subject of higher education research/studies, Turkey

\section{ÖZ}

Bu araştırma 2015-2019 yılları arasında yayımlanan 256 bilimsel makale/tez verisi üzerinden Türk yükseköğretim araştırmalarının öznesi olarak öğretim üyelerine odaklanan çalışmaları incelemeyi amaçlamaktadır. Elde edilen verileri gözden geçirmek ve sınıflandırmak üzere araştırma ve araştırmacılar hakkında genel bilgi, çalışma nesnesi ve bilgi nesnesi unsurlarına dayalı analitik bir çerçeve kullanılmışır. Öğretim üyelerine odaklanan Türk yükseköğretim araştırmalarının ağırlıklı olarak Türkçe hakemli dergilerdeki akademik makalelerde ele alındığı tespit edilmiştir. Birincil çalışma konuları, öğretme ve öğrenme, politika çalışmaları, kimlik geliştirme ve kurumsal araştırma ile ilgili temalar ve araştırma ve öğretim alanlarını kapsamaktadır. Bilgi nesnesi açısından öğretim üyelerine odaklanan Türk yükseköğretim çalışmalarının betimleyici bir özelliğe sahip olduğu tespit edilmiştir. Nicel çalışmalarda maksimum 400 katılımcı ile birlikte parametrik testler ile kendini örnekleyen evren ve basit tesadüfi örnekleme yöntemleri kullanılmıştır. Nitel araştırmalar, veri toplamak için görüşmelerden ve analiz yöntemi olarak içerik analizinden yararlanmıştır. Çalışma öğretim üyelerinin sadece akademik çıktılarına değil, seçimlerine, kariyer süreçlerine ve emeklilik süreçleri gibi uzun dönemli periyodik ve sürdürülebilir araştırma yapıları kurgulanması gibi önerilerle tamamlanmıştır.

Anahtar Sözcükler: Öğretim üyeleri, Araştırmacılar, Yükseköğretim araştırmalarının öznesi, Türkiye

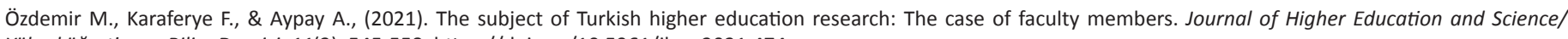
Yükseköğretim ve Bilim Dergisi, 11(3), 545-558. https://doi.org/10.5961/jhes.2021.474

Murat ÖZDEMIR (ه)

ORCID ID: 0000-0003-2041-211X

Anadolu University, Faculty of Education, Department of Educational Administration, Eskişehir, Turkey Anadolu Üniversitesi, Eğitim Fakültesi, Eğitim Yönetimi AD, Eskişehir,Türkiye

muratozdemir37@yahoo.com

Figen KARAFERYE

ORCID ID: 0000-0003-3449-032X

Kütahya Dumlupınar University, Child Care \& Youth Services, Emet Vocational School, Kütahya, Turkey Kütahya Dumlupınar Üniversitesi, Çocuk Gelişimi Programı, Emet MYO Yerleşkesi, Kütahya, Türkiye

Ahmet AYPAY

ORCID ID: 0000-0003-0568-8409

Anadolu University, Faculty of Education, Department of Educational Administration, Eskişehir, Turkey

Anadolu Üniversitesi Eğitim Fakültesi, Eğitim Yönetimi AD, Eskişsehir, Türkiye

Received/Geliş Tarihi : 12.07.2021

Accepted/Kabul Tarihi : 15.12.2021 


\section{INTRODUCTION}

The growth in higher education institutions has been phenomenal in the past forty years and the number of students is predicted to be over 265 million by 2025 in the world (Noui, 2020). Turkish higher education experienced a similar growth trend. Before 1990, there were only 30 universities (29 state and 1 private-foundation). From 1991 and 2000, 42 new universities (19 state, 23 private-foundation) were established. 90 new universities (41 state and 49 private-foundation) were created between 2001-2010, and 47 new universities (26 state and 21 private-foundation) were established between 20112021. Since the 1990s, universities geographically distributed around the country following an aggressive expansion strategy (Özoğlu, Gür \& Gümüs, 2016). The number of state universities almost doubled from 53 in 2005 to 104 in 2014 and increased to 129 as of 2021. As of mid-December 2021, there were 181.507 faculty (full, associate, and assistant professors, lecturers, and research assistants) employed in a total of 204 higher education institutions located at least one university in each province. However, the number of faculty was 142.437 at 181 universities as of June 2014 (Higher Education Information Management System [HEIMS], 2021). Statistics indicate that the number of academics increased approximately $25 \%$ while the number of universities increased $15 \%$ just in seven years.

HEIMS (2021) provides exhaustive statistics for the Turkish Higher Education system based on several variables annually. By mid-December 2021, 67\% of faculty were full professors $(\mathrm{N}=21.323), 60 \%$ were associate professors $(\mathrm{N}=11.309), 55 \%$ were assistant professors $(\mathrm{N}=22.472), 49 \%$ were lecturers $(\mathrm{N}=18.758)$, and $48 \%$ were research assistants $(\mathrm{N}=24.821) .54 \%$ of total academics $(\mathrm{N}=98.683$ ) were males while $33 \%$ of full professors $(\mathrm{N}=10.489), 40 \%$ of associate professors $(\mathrm{N}=7.585)$, $45 \%$ of assistant professors $(\mathrm{N}=18.651)$ were females. Moreover, $51 \%$ of lecturers ( $\mathrm{N}=19.245)$, and $52 \%$ of research assistants $(\mathrm{N}=26.854), 46 \%$ of total academics $(\mathrm{N}=82.824)$ were females. By the beginning of 2020-2021 academic year, the distribution of faculty was as follows: Health \& Welfare by $28 \%(\mathrm{~N}=50.991)$, Engineering, Manufacturing \& Construction by $14 \%(\mathrm{~N}=25.609)$, Arts \& Humanities by $14 \%(\mathrm{~N}=25.220)$, Natural Sciences, Mathematics \& Statistics by $10 \%(\mathrm{~N}=17.330)$, Business, Administration \& Law by $9 \%(\mathrm{~N}=16.776)$, Education by $6 \%(\mathrm{~N}=10.147)$, unclassified by $6 \%(\mathrm{~N}=10.045)$, Social Sciences, Journalism \& Information by $5 \%(\mathrm{~N}=9.390)$, Services by $3 \%(N=5.758)$, Agriculture, Forestry, Fisheries \& Veterinary by $3 \%(\mathrm{~N}=5.292)$, Information \& Communication Technologies by $2 \%(\mathrm{~N}=3.127)$. However, no information about diversity was available in the Turkish higher education context. Table 1 presented the distribution of academics in Turkish higher education by fields of education and training ( $n=179.685)$.

The worldwide massification of postsecondary education has led to an increase in higher education research concerning the output of universities (Rumbley, Altbach, Stanfield, Shimmi, de Gayardon, \& Chan, 2014; Tight, 2012). Rumbley, Stanfield \& de Gayardon (2014) reported that there have been ever-growing efforts for higher education studies in developing countries recently. There were eight Centres for Higher Education Studies in İstanbul (4), Ankara (1), Çanakkale (1), Sakarya (1), and Zonguldak (1). The number of Application \& Research Centres on the rise since 2011. The mission statements indicated that they are expected to be active both in theory and practice in higher education research. Two master's degree programs existed: Higher Education Administration at Eskişehir Osmangazi University and Higher Education Studies at Sakarya University (Aypay, 2015; Gök \& Gümüş, 2015; HEIMS, 2021). Professional organizations have also emerged in Turkey. Higher Education Strategy and Research Association (YÖSAD) and the Association for Higher Education Studies (YÖÇAD) were established after 2013 (Akbulut Yıldırmış \& Seggie, 2018). Moreover, four specialized higher education journals namely Journal of Higher Education (Turkey), Journal

Table 1: The Distribution of Turkish Academics by Fields of Education and Training

\begin{tabular}{|c|c|c|c|}
\hline & $\begin{array}{l}\text { Undergraduate } \\
\text { programs }\end{array}$ & $\begin{array}{l}\text { Vocational training } \\
\text { school }\end{array}$ & $\begin{array}{l}\text { Graduate schools/ } \\
\text { Application \& } \\
\text { Research Centres }\end{array}$ \\
\hline Information \& communication tech & 1.912 & 1.132 & 83 \\
\hline Natural sciences, mathematics \& statistics & 16.669 & 339 & 322 \\
\hline Education & 10.126 & 0 & 21 \\
\hline Services & 2.951 & 2.799 & 8 \\
\hline Business, administration \& law & 11.930 & 4.818 & 28 \\
\hline Engineering, manufacturing \& construction & 20.580 & 4.766 & 263 \\
\hline Health \& welfare & 44.402 & 4.963 & 1.626 \\
\hline Arts \& humanities & 23.108 & 1.983 & 129 \\
\hline Social sciences, journalism \& information & 8.678 & 602 & 110 \\
\hline Agriculture, forestry, fisheries \& veterinary & 3.983 & 1.295 & 14 \\
\hline Unclassified & 8.140 & 562 & 1343 \\
\hline Total & 152.479 & 23.259 & 3.947 \\
\hline
\end{tabular}


of Higher Education and Science, Journal of University Research, and Higher Education Governance and Policy were created to publish higher education research. They are either affiliated with professional organizations or research centres at universities. Certainly, all these efforts contributed to the study of higher education researchers/academics in Turkey. Teichler (2000: 19-21) suggested a typology of higher education experts including "the discipline/department-based occasional researchers on higher education, the continuous disciplinebased higher education researchers, the scholars based in a higher education research institute or unit, the applied higher education researchers, the consultants of higher education, the reflective practitioners." However, a limited number of higher education researchers focused solely on the study of higher education. Thus, there is room for an increase in the number of faculty who devote their research to the study of higher education.

Higher Education Research was included in the main field of Social, Humanities, and Administrative Sciences in 2015 as one of the specializations of associate professorship by the Interuniversity Board (UAK). It is particularly important as it signifies the scholarly recognition of the study of higher education as a field of study. The keywords of the field were listed as open and distance learning, lifelong learning, equity and equality, gender, finance, policies, systems, management, quality assurance, program development and competencies, and internationalization (UAK, 2021). It may be considered as a delayed response concerning the rapid expansion in the Turkish higher education context (Akbulut Yıldırmış \& Seggie, 2018).

All the constituents agree on the vital role of qualified faculty members in higher education. Numerous studies reported that the number of qualified faculty members was limited in the supply side in Turkish higher education. The two major problems were claimed to be the concentration of faculty members in the largest three metropolitan cities (Istanbul, Ankara, and izmir) and the uneven distribution of faculty among departments, faculties, and universities (Doğan, 2013; Özen \& Koçak, 2015; Özer, 2011). Similarly, promotion, academic freedom, the training of researchers and faculty members, and quality in education were among the major issues in higher education in Turkey (Küçükcan \& Gür, 2009). The scarcity of 'qualified faculty' has been a significant challenge regardless of the characteristics of higher education institutions (Özen \& Koçak, 2015; Özoğlu, Gür \& Gümüs, 2016).

The research on faculty members is also overlooked as one of the subjects of Turkish higher education research. To exemplify, the number of all the graduate theses entitled "faculty member" was only 101 in June 2021 in the Turkish National Thesis Centre database. Besides, there were 530 others entitled "instructors", 311 of them entitled "academics." While the graduate theses entitled "faculty member" and "instructors" dated back to 1990, those entitled "academics" to 1986 . The accumulation of Turkish higher education studies addressing the faculty members as the subject of Turkish higher education research is limited in number when the grand total of available theses (778.034) are considered in the Turkish National Thesis Centre database since 1959. Therefore, the present study aimed to examine the research focusing on faculty members as the subject of Turkish higher education research between the years 2015-2019. In line with the main aim of the study, the study seeks answers to the following questions:

- What are the characteristics of Turkish higher education research and researchers on faculty members?

- How research on faculty may be classified by Mcfarlane's (2012) higher education research archipelago and by Boyer's (1990) models of scholarship?

- What are the methodologies (research design, data sources, data analyses, and sampling) utilized by research on faculty?

\section{METHODOLOGY}

The study explored online databases (Ulakbim, Dergipark, Academic Search Complete, Scopus, Complementary index, Idealonline, Supplemental index, Business Source Complete, Turcademy) via Ebsco and Turkish National Thesis Centre database to review the research focusing on faculty members. The study focused on all the evaluative or judgemental elements rather than the main content areas in academic papers/dissertations (Clement et al., 2015). For the academic papers and dissertations, the duplicates were eliminated manually and automatically. Moreover, the articles beyond the predetermined themes and categories were removed manually as they were deemed to be irrelevant. For the dissertations, the parameters of search in "all", access type "authorized", and thesis type "doctorate" and "master" were respectively used for the screening in July 2019. The search in parameter included the other options of the title, author, supervisor, subject, keyword, and abstract. The access type parameter provided us with an opportunity to uncover more studies without authorization. They consisted of studies that are out of scope in terms of the selected period and/or restricted theses by their authors. Some of the theses were also excluded based on the examination of abstracts and keywords. Lastly, the thesis type parameter also offered the options of all, specialization in medicine, proficiency in art, specialization in dentistry, minor specialization in medicine. Understandably, covering master's and doctoral theses was the most convenient choice for addressing the research objective. At the end of the data collection procedure, 256 records between the years 2015-2019 were obtained based on a search with the keywords of instructors, faculty members, and academicians for academic papers, and the search terms of faculty, academics, and academic administrators for dissertations. The present study elaborated the content of the publications though it determined the research sample mainly by their titles, abstracts, and keywords. This should be regarded as both the originality and the limitation of the study. The data collection procedure was illustrated below.

Apart from the frequencies and percentages, the distributions by type of research, number of authors, research themes/ 


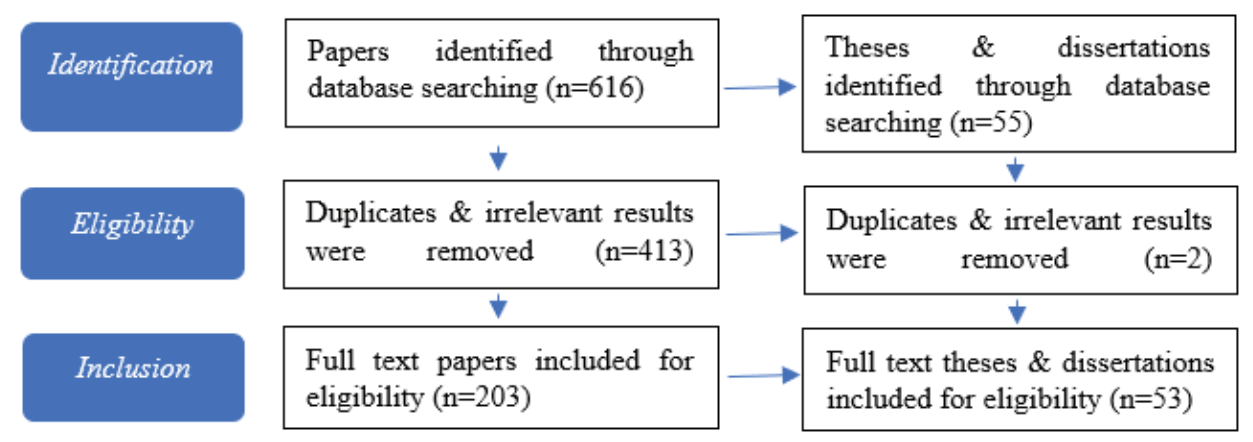

Figure 1: Identification of sample.

categories, research methods, number of participants, data sources, data analysis methods, and sampling procedures were collected to study the research focusing on faculty members as the subject of Turkish higher education research. Furthermore, Boyer's (1990) four domains of scholarship were used as an analytical framework. The scholarship of discovery refers to the generation of knowledge and publications while the scholarship of integration involves the integration of research results and interdisciplinary knowledge. Moreover, the scholarship of application focuses on applying disciplinary skills and knowledge to institutional and societal practical problems while the scholarship of teaching aims at selecting, organizing, and transforming knowledge (Braxton, Luckey, \& Helland, 2002). The review starts with 2015 when Higher Education Research was included in the Core Field of Social, Humanities, and Administrative Sciences in 2015 as one of the basic fields of associate professorship by the Interuniversity Board (UAK, 2021). The islands suggested by Macfarlane (2012) in his article entitled "The Higher Education Research Archipelago" were adopted in the creation of the research themes/categories. It acknowledges six distinct domains within higher education research as follows:

1. Teaching and learning: Program design and development, pedagogical research, the roles of faculty members (knowledge production, teaching, and learning), e-learning, PhD/ Master's students/consulting, career development, measurement and evaluation, learning theory, student's personality development, educational sociology, ethnography, gender, culture, and learning, and student assessment

2. Policy studies: Equality and access, government policy analysis (higher education and science policies of Council of Higher Education - $\mathrm{CHE}$ ), national systems, employment and career, internationalization, ranking and comparing, quality control, globalization, finance and economy, historical and comparative analysis, marketization, and school dropout

3. Institutional research

4. Identity development

5. Professional development: Professionalization (publication, production, assignment, promotion), and portfolio
6. Philosophy: Ethics/morality, misconduct, and plagiarism

It should be noted that the higher education research archipelago is based on experience and intuition rather than empirical data and the first two were the main islands (Calma \& Davies, 2017). In addition to the above themes, Vocational \& Technical Education Faculty was added as the seventh alternative by the researchers. The study sample was categorized into articles, master's theses, and PhD dissertations. Research methods comprised three major research paradigms, namely quantitative, qualitative, and mixed. The sampling procedures included three major research traditions of quantitative, qualitative, and mixed methods and the studies were grouped individually. We were inspired by a frame of reference suggested by Forsberg \& Geschwind (2016) to identify data sources involving surveys, interviews, documents, observations, checklists, metaphorical, and enrolment data. We also incorporated the mixed-use of data sources as a supplementary alternative. Data analysis procedures were classified under parametric/nonparametric tests, descriptive/content analyses, and literature/systematic reviews along with the frequencies and percentages. The number of researchers and participants were also explored to shed light on sample size and the background of researchers.

\section{FINDINGS}

The purpose of the study was to examine the research focusing on faculty members as the subject of Turkish higher education research. We maintained three levels of structuring research proposed by Askling (2004 cited in Forsberg \& Geschwind, 2016) to be not only informative but also inclusive and explanatory. At first, demographic information was presented on the subject of Turkish higher education research and researchers under the heading of The General Information about Research and Researchers. Secondly, the higher education research themes and the model of scholarship were explored under the heading of The Object of Study. Finally, we analysed the research designs, data sources, data analysis, and sample selection under the heading of The Object of Knowledge. Conceptual mapping of Turkish higher education research focusing on faculty members included;

- Research designs: Descriptive, correlational, case study, phenomenology, review, and feminist methodology; 
- Data sources: Surveys, interviews, documents, metaphorical data, observations, checklists, enrolment data, and mixed data sources;

- Data analysis: Descriptive, parametric/nonparametric tests, descriptive/content analyses, and literature/systematic reviews;

- Sample selection: The sampling of participants and sample selection procedures.

\section{The General Information about Research and Researchers}

The findings regarding the characteristics of Turkish higher education research and researchers were presented in this section. At the end of the data collection procedure, 256 records between the years 2015-2019 were obtained based on the Turkish equivalents for the search terms of "instructors, faculty members and academics" for papers, and the search terms of "faculty, academics, and academic administrators" for dissertations. The elimination of the duplicates and irrelevant results manually was a major problem exclusively for the academic papers as they were reiterated more than three times. Fortunately, it was easier to obtain dissertations as the rate of reiteration was negligible $(n=2)$. Figure 2 depicted research focusing on faculty members as the subject of Turkish higher education research by academic work $(n=256)$.

It was clear in Figure 2 that faculty members were predominantly addressed by academic papers $(79.30 \%)$ in peer-reviewed journals between the years 2015-2019. Moreover, the frequencies of master's theses and doctoral dissertations were quite similarly low. Furthermore, the majority of studies ( $n=233 ; 91.02 \%$ ) were written in Turkish. 20 of them were in English while three papers had both Turkish and English versions. All the academic papers, theses, and dissertations had abstracts in English. One article in German was excluded as the Turkish abstract did not contain relevant information for this study. Figure 3 demonstrated research focusing on faculty members as the subject of Turkish higher education research by the number of authors $(n=256)$.

Figure 3 indicated that almost two-fifth of the total studies focusing on faculty members as the subject of Turkish higher education research was carried out by a single author. More than two-thirds of the research had two authors. Three author studies (19.9\%) were higher than expected, and collaborations by four or more researchers were lower (7.9\%). A pinpoint remainder was that there was a balanced distribution by year of publication. Accordingly, $43(16.8 \%)$ of the studies were published in 2015, 54 (21.1\%) of them were in 2016, 40 (15.6\%) of them were in 2017, $66(25.8 \%)$ of them were in 2018, and 53 (19.5\%) of them were in 2019.

\section{The Object of Study}

The findings regarding higher education research themes and the domains of scholarship were addressed in this section. Figure 4 illustrated the distribution of themes in research on faculty members as the subject of Turkish higher education research $(n=256)$ based on the higher education research archipelago.
The above figure implied that the research sample mainly focused on teaching and learning, policy studies, identity development, and institutional research respectively. These four themes had an $87 \%$ in total. Other themes like philosophy, professional development, and vocational \& technical education faculty did not receive a great deal of scholarly attention. Although it was not surprising that almost onethird of the research focused on teaching and learning on faculty members, all the themes were received some scholarly attention. Table 2 elaborated the research themes on faculty members as the subject of Turkish higher education research by categories $(n=256)$.

Table 2 presented a more detailed picture of the research themes adopted. It was clear that three of seven research themes - identity development, institutional research, and vocational \& technical education faculty - did not contain any categories. Program design and development, and pedagogical research were the most salient categories for the theme of teaching and learning while equality and access, and government policy analysis were notable in the theme of policy studies. All the studies in the theme of professional development were on types of professionalization, and the category of ethics/morality was exclusively dominant in the theme of philosophy. Furthermore, the categories for the

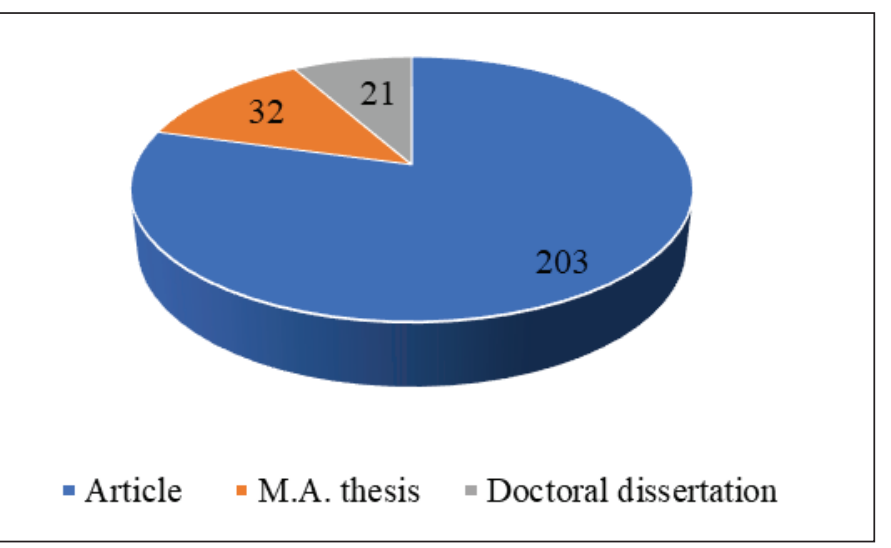

Figure 2: The subject of Turkish higher education research by academic work.

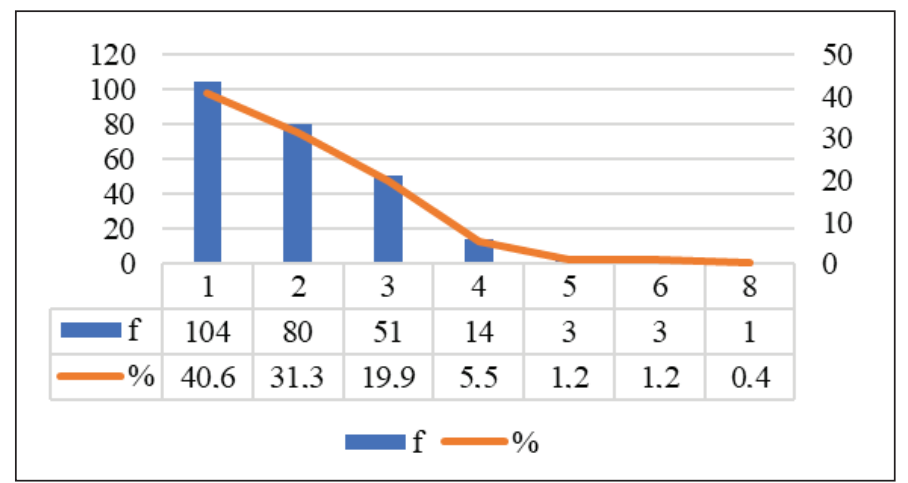

Figure 3: The subject of Turkish higher education research by the number of authors. 


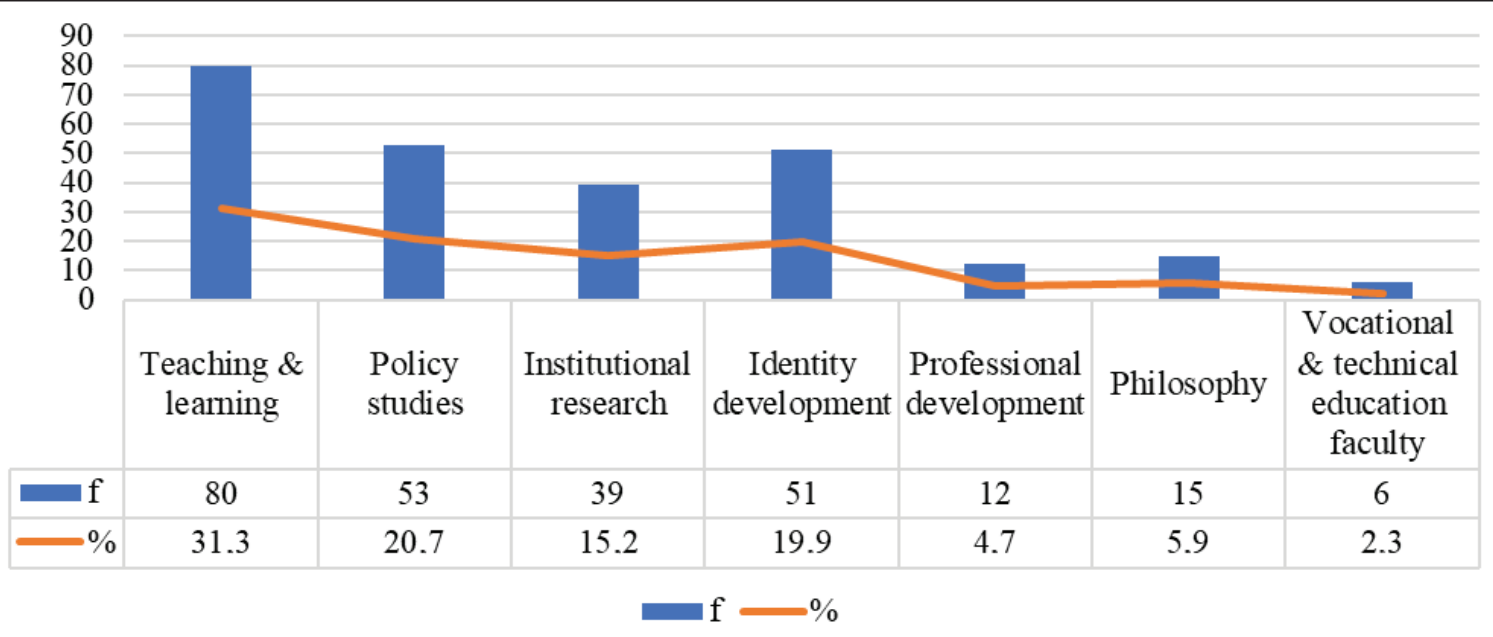

Figure 4: Faculty as the subject of Turkish higher education research by research themes.

Table 2: Faculty as the Subject of Turkish Higher Education Research by Macfarlane's (2012) Themes/Categories

\section{Themes}

Teaching and learning

Policy studies

Professional development

\section{Philosophy}

Identity development Institutional research Vocational \& technical education faculty

\section{Categories}

Program design and development

Pedagogical research

The roles of faculty members (knowledge production, teaching, and learning)

E-learning

PhD/Master's students/consulting

Career development

Measurement and evaluation

Learning theory

Student's personality development

Educational sociology

Ethnography

Gender, culture, and learning

Student assessment

Equality and access

Government policy analysis (higher education and science policies of CoHE)

National systems

Employment and career

Internationalization

Ranking and comparison

Quality control

Globalization

Finance and economy

Historical and comparative analysis

Marketization

School dropout

Professionalization (publication, production, assignment, promotion)

Portfolio

Ethics/morality

Plagiarism

N/A

N/A

N/A

Total 
roles of faculty members, e-learning, $\mathrm{PhD}$ /master's students/ consulting, national systems, employment, and career and internationalization had relatively higher frequencies. Table 2 rendered the divergence of categories rather than main themes. Table 2 also indicated that few studies explore career development, measurement and evaluation, learning theory, student personality development, educational sociology, ethnography, gender, culture and learning, student assessment, ranking and comparison, quality control, globalization, economics and finance, historical and comparative analysis, marketization, school dropout, portfolio, and misconduct. Figure 5 introduced the four domains of scholarship for research on faculty members as the subject of Turkish higher education research $(n=256)$.

Boyer's (1990) model involved the scholarships of discovery, teaching, application, and integration. It was clear in Figure 5 that the scholarship of discovery dominated research on faculty members. Moreover, the scholarship of teaching, the study of educational approaches and interventions

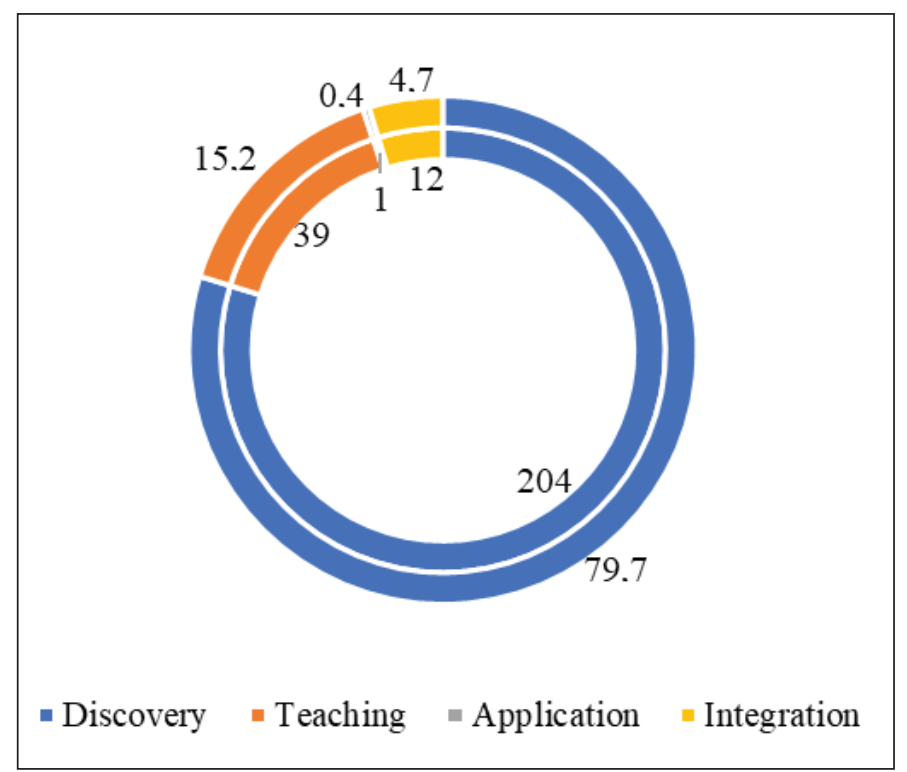

Figure 5: Faculty as the subject of research based on Boyer's (1990) four domains of scholarship. to comprehend learning, was also significant with $15,2 \%$. However, the scholarship of integration, making connections across disciplines, received less attention. Lastly, the scholarship of application, concentrating on using scientific outcomes to remedy social and institutional challenges, was the subject of only one study. It indicated that research focusing on faculty members $(n=256)$ did not intend or attempt to exploit conventional research results to real-life problems of society and the academy. Table 3 elaborated the classification of research on faculty members by four domains of scholarship and by research themes $(n=256)$.

Table 3 indicated that the scholarship of discovery was dominant all but the scholarship of teaching among the research on faculty members. It was evident that there were few or no studies for the scholarship of application. Teaching and learning, and policy studies themes included studies categorized under the scholarship of integration, albeit in limited number.

\section{The Object of Knowledge}

The findings regarding the methodologies of research on faculty were investigated in this section. Table 4 presented the distribution of research methods used in research on faculty as the subject of Turkish higher education research $(n=256)$ based on the higher education research archipelago.

Table 4 indicated that the quantitative research paradigm was dominant for all research themes in research on faculty members except for the themes of teaching and learning, and policy studies. These two themes primarily adopted the qualitative paradigm. On the other hand, the themes of teaching and learning, institutional research, and identity development were found to be marginally exposed to mixed-method studies. Although there was a balance among quantitative, qualitative, and mixed-method research for the professional development theme, research on the vocational \& technical education faculty was quite limited. Table 5 demonstrated the distribution of research methodologies on faculty members $(n=256)$ based on the four domains of scholarship.

Table 5 adds another dimension to the discussion. It was clear that the qualitative research paradigm was dominant for all

Table 3: The Classification of Research on Faculty by Four Domains of Scholarship

\begin{tabular}{|l|c|c|c|c|c|}
\multirow{2}{*}{} & \multicolumn{3}{|c|}{ Boyer's Model of Scholarship } & \multirow{2}{*}{ Total (n) } \\
\cline { 2 - 5 } & Discovery & Teaching & Application & Integration & \\
\hline Teaching and learning & 15.6 & 14.1 & 0.4 & 1.2 & 80 \\
\hline Policy studies & 17.6 & 0.0 & 0.0 & 3.1 & 53 \\
\hline Institutional research & 14.8 & 0.4 & 0.0 & 0.0 & 39 \\
\hline Identity development & 19.1 & 0.4 & 0.0 & 0.4 & 51 \\
\hline Professional development & 4.7 & 0.0 & 0.0 & 0.0 & 12 \\
\hline Philosophy & 5.9 & 0.0 & 0.0 & 0.0 & 15 \\
Vocational \& technical education faculty & 2.0 & 0.4 & 0.0 & 0.0 & 6 \\
\hline Total (\%) & 79.7 & 15.2 & 0.4 & 4.7 & 256 \\
\end{tabular}


domains of scholarship on faculty members as the subject of Turkish higher education research except for the scholarship of discovery which primarily adopted the quantitative paradigm. It was not extraordinary that the research on the scholarship of discovery was dominated by the quantitative paradigm as it is more concerned with knowledge generation. Moreover, the scholarship of discovery and the scholarship of teaching were likely to use different methodologies while the former is to produce new knowledge and the latter is to study educational methods and build bridges to comprehend learning. On the other hand, the scholarship of application and the scholarship of integration employed the qualitative research paradigm to a great extent to bring new insights for the use of knowledge across disciplines and to address social and professional challenges. Figure 6 provided the research designs by three major research paradigms for research focusing on faculty $(n=256)$.

Table 4: The Distribution of Methodologies by Research Themes

\begin{tabular}{|l|c|c|c|c|}
\hline & Quantitative & Qualitative & Mixed & Total (n) \\
\hline Teaching and learning & 10.2 & 17.2 & 3.9 & 80 \\
\hline Policy studies & 8.2 & 11.7 & 0.8 & 53 \\
\hline Institutional research & 11.3 & 2.7 & 1.2 & 39 \\
\hline Identity development & 13.7 & 4.7 & 1.6 & 51 \\
\hline Professional development & 2.0 & 2.0 & 0.8 & 12 \\
\hline Philosophy & 4.7 & 0.8 & 0.4 & 15 \\
\hline Vocational \& technical education faculty & 1.2 & 0.8 & 0.4 & 6 \\
\hline Total (\%) & 51.2 & 39.8 & 9.0 & 256 \\
\hline
\end{tabular}

Table 5: The Distribution of Methods by Four Domains of Scholarship

\begin{tabular}{l|c|c|c|c|}
\hline & Quantitative & Qualitative & Mixed & Total $(\mathbf{n})$ \\
\hline Discovery & 46.9 & 26.2 & 6.6 & 204 \\
\hline Teaching & 4.3 & 8.6 & 2.3 & 39 \\
\hline Application & 0.0 & 0.4 & 0.0 & 1 \\
\hline Integration & 0.0 & 4.7 & 0.0 & 12 \\
\hline Total (\%) & 51.2 & 39.8 & 9.0 & 256 \\
\hline
\end{tabular}

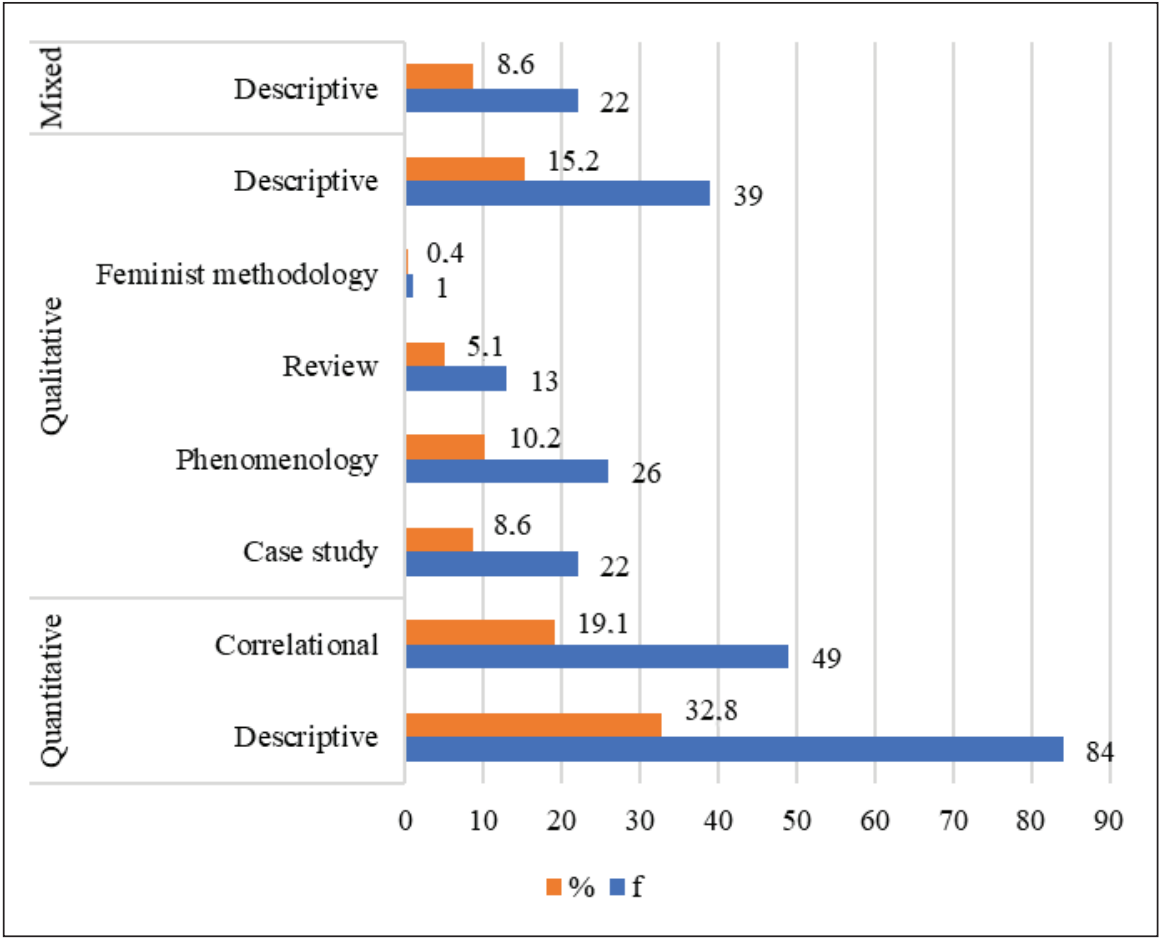

Figure 6: The classification of research on faculty by research designs. 
Figure 6 presented a more detailed picture of the research designs utilized in the research. Although there was a strong emphasis on quantitative methods with $51,9 \%$, some variation was observed for the research designs. It was clear that studies in social sciences used correlational designs, reviews, phenomenology, and case studies. However, research on faculty members was overwhelmingly descriptive in nature regardless of the use of qualitative, quantitative, or mixed methods. A small number of studies used action research, discourse analysis, experimental research, ethnography, developmental, and phenomenography. Figure 7 included the distribution of data collection methods on faculty members as the subject of Turkish higher education research $(n=256)$.

Figure 7 revealed that several types of data collection procedures were used by the researchers on faculty members.
First, the prevalence of surveys was the norm. It was also interesting to see that the mixed-use of data collection procedures and interviews were quite common. Surveys, interviews, documents, and the use of mixed data sources $(96,9 \%)$ were so central that the use of metaphors, checklists, observations, and enrolment data was almost non-existent. Figure 8 presented the distribution of research on faculty members as the subject of Turkish higher education research by data analysis procedures $(n=256)$.

As indicated earlier, studies used quantitative methods by $50 \%$, qualitative methods by $40 \%$, and mixed methods by $10 \%$. Figure 8 indicates that the parametric tests were employed in quantitative studies while content analysis was preferred in qualitative ones to a great extent. Furthermore, a small number of studies analysed only descriptive data. In addition,
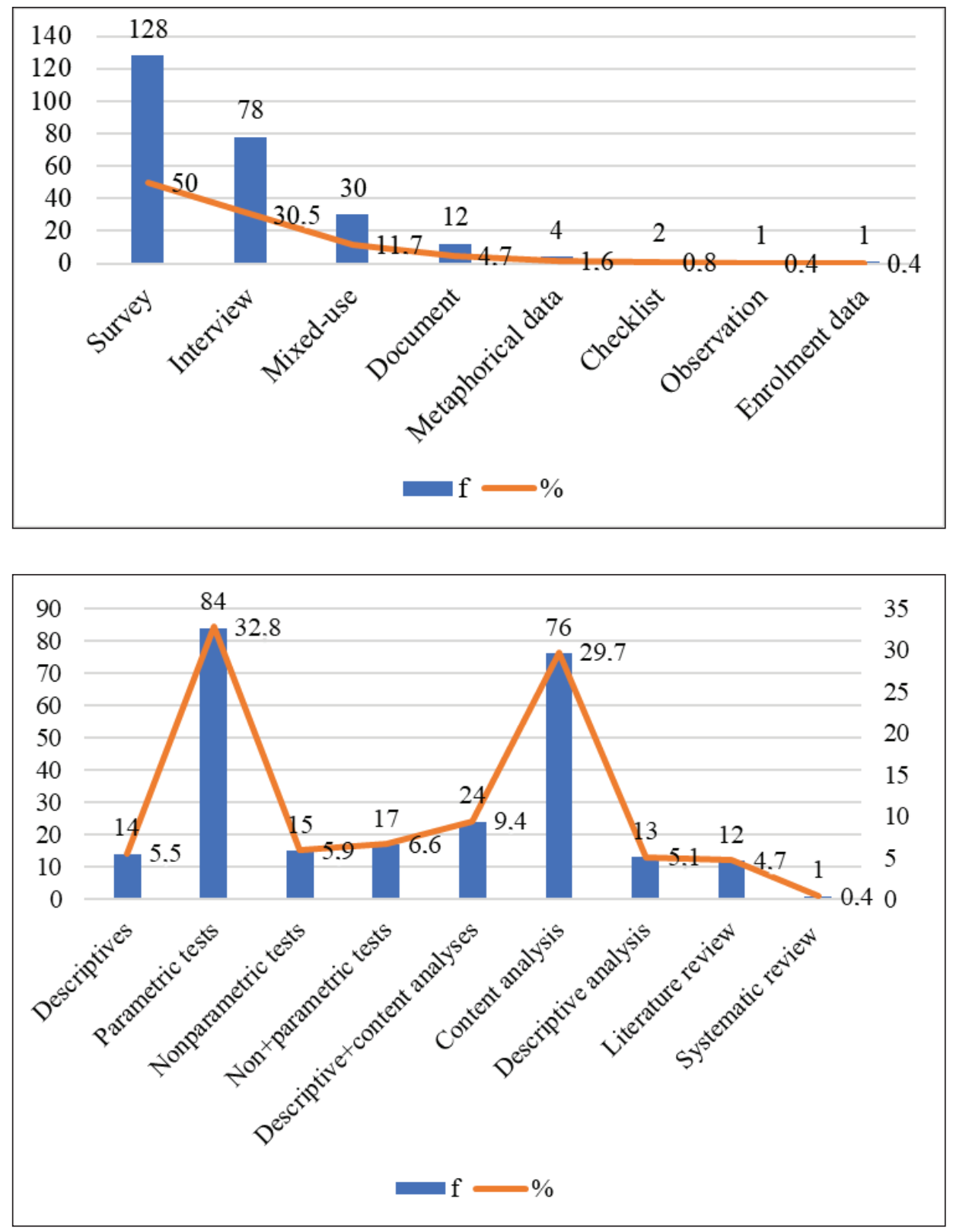

Figure 7: Faculty as the subject of Turkish higher education research by data sources.
Figure 8: The subject of research on faculty members by data analysis procedures. 
the researchers hardly ever attempted to conduct systematic reviews in research on faculty members as the subject of Turkish higher education research. Figure 9 depicted the distribution of the number of participants in research focusing on faculty members as the subject of Turkish higher education research by two major research paradigms $(n=256)$.

Based on Figure 9, it was clear that the quantitative studies were mostly carried out with small samples (number of participants under 200 with 52.1\%). Almost nine out of ten studies in the relevant literature used a medium sample size (up to 400 individuals). Only 17 research studies included large samples (over 401 respondents). One-third of the qualitative research on faculty members as the subject of Turkish higher education was conducted with less than 10 participants, between 11-20 participants, and over 21 participants on a par. Two-thirds of qualitative studies had up to 20 participants. This finding is in line with the qualitative paradigm that the sample is usually purposeful and sample size depends on the saturation of data. Figure 10 provided the distribution of sampling procedures in research on faculty members as the subject of Turkish higher education research by two major research paradigms $(n=272)$.

Figure 10 demonstrated that the divergent sampling procedures were employed by different research paradigms as expected. A large majority of quantitative studies used no sampling/target population or simple random sampling (26.1\% of grand total) while criterion sampling and maximum variation sampling were the most frequently used for the qualitative ones $(15.8 \%$ of grand total). It was highly remarkable that convenience sampling was employed by both research paradigms though it was categorized under purposeful sampling procedures. When both methodologies were considered, one-seventh of the studies used convenience sampling (16.2\%). For the quantitative studies, it creates problems for generalizability while it is natural for the qualitative study of faculty members as qualitative research sampling is purposeful. Additionally, 16 studies reported using two different sampling procedures. Lastly, no sampling procedures were identified in almost one-third of studies to point out the issues of generalizability, validity, and reliability. It is important to note that only three (1.2\%) of 256 studies examined in this study used probability sampling rather than the ones with purposeful sampling $(n=59$, 23.0\%). Contrary to the expectations, three out of four studies $(n=194,75.8 \%)$ in the study sample did not report sampling procedures.

\section{CONCLUSIONS \& IMPLICATIONS}

The research results were three-fold. The first one was on the general information about research and researchers on faculty. Research on faculty was overwhelmingly published as academic papers in peer-reviewed journals rather than theses. The majority of studies were published by one author (41\%) and in Turkish with abstracts in English. More than two-thirds of the studies were authored by two researchers, and onefourth of them were published collaboratively by three and four authors. There was a balanced distribution throughout the four-year period by year of publication from 2015 to 2019. 2015 was a milestone in the history of Turkish higher education faculty since Interuniversity Board (UAK) recognized Higher Education Research as a scholarly field and included it within Social, Humanities, and Administrative Sciences as a specialization for promotion. This is highly important as it is likely to lead to the opening of academic positions for scholars specialized in the study of higher education.

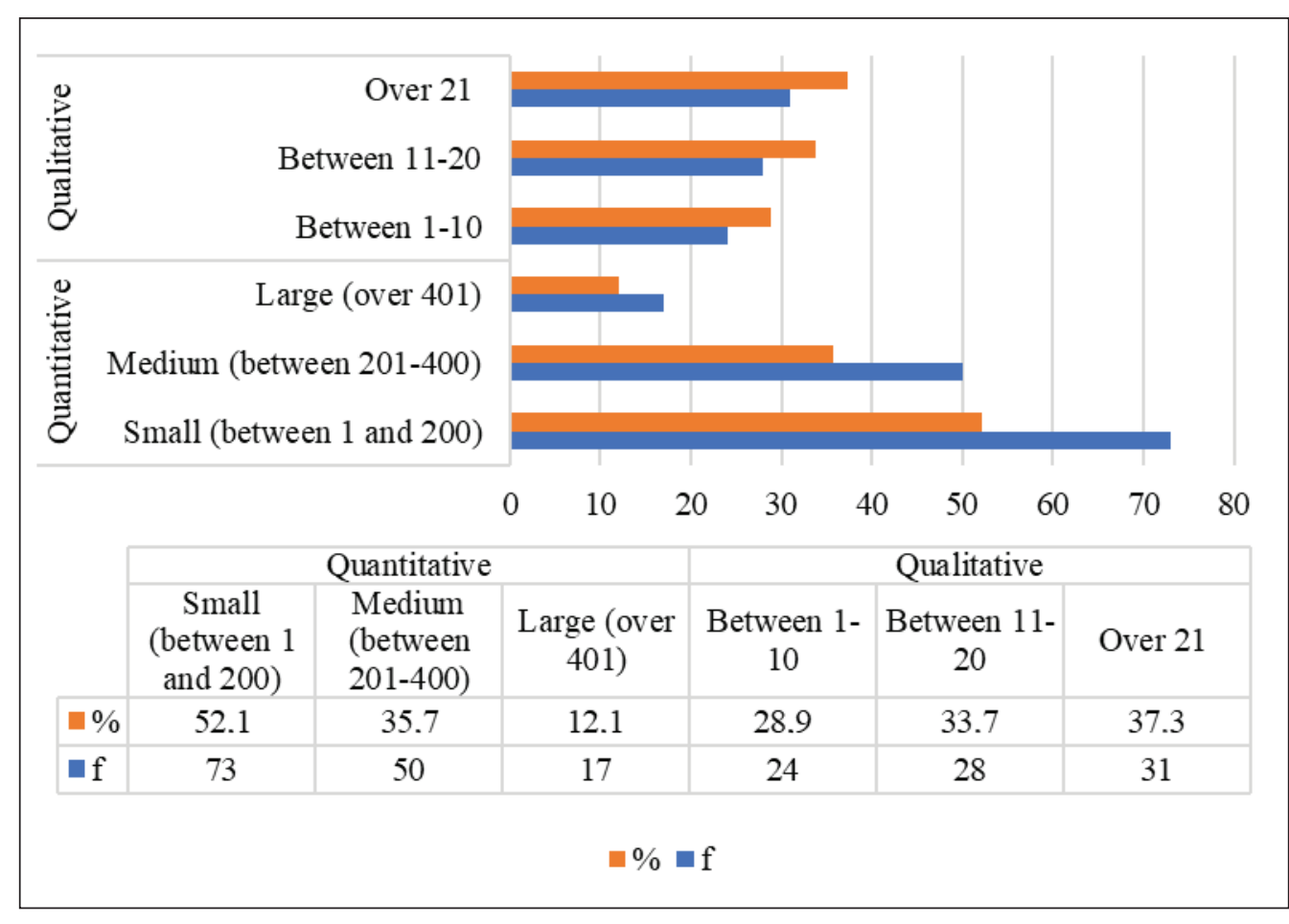

Figure 9: Faculty as the subject of Turkish higher education research by the number of participants. 


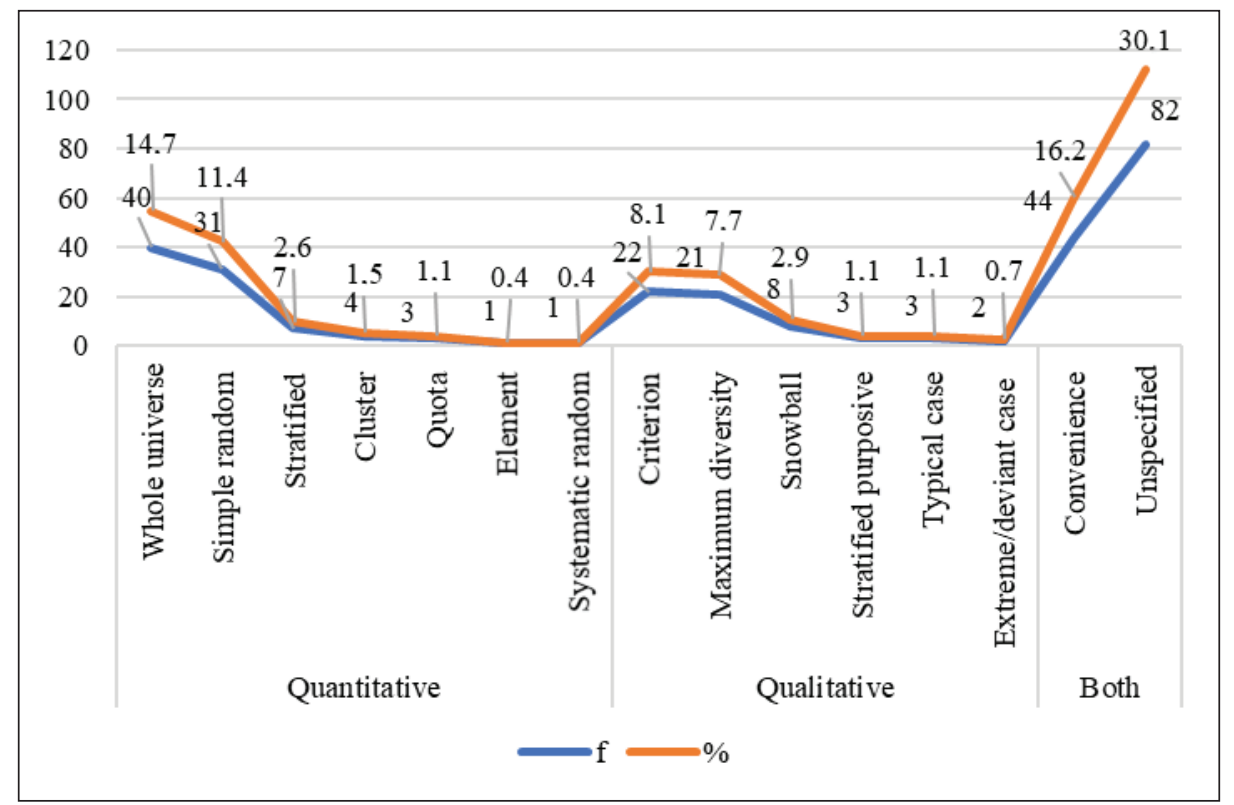

Figure 10: Faculty as the subject of Turkish higher education research by sampling procedures.
The second one was about the object of study. The islands of teaching and learning, policy studies, identity development, and institutional research were dominant concerning the higher education research archipelago. Accordingly, program design and development and pedagogical research were the salient categories for teaching and learning while equality and access, and government policy analysis distinguished in policy studies. All the studies in professional development were on professionalization, and the category of ethics/morality was exclusively prevalent in philosophy. The scholarship of discovery dominated research on faculty members among the four domains of scholarship. The scholarship of teaching had a subordinate role.

The third one was about the object of knowledge. The quantitative research paradigm was commonly used in research on faculty members with some exceptions. However, almost half of the studies (46\%) used a quantitative approach, nearly one-fourth of them used a qualitative approach, and only $7 \%$ of the studies used mixed-method in the scholarship of discovery. An analysis by research designs yielded that research on faculty members was mostly descriptive in nature regardless of the use of qualitative, quantitative, or mixed-methods. Only $12 \%$ of the quantitative studies using surveys/parametric tests had large samples. This may be an indication of the challenges of collecting data from faculty members. In quantitative studies, collecting data from the target population (not using a certain sampling procedure) and simple random sampling were widely used. Interviews and content analysis were adopted mainly as the data collection and analysis procedure. Criterion and maximum variation sampling were frequently employed in the sampling of research on faculty members. However, the sampling procedures were not reported accurately.

Our findings summarized Turkish higher education research specifically on faculty members. This is the contribution and the original aspect of the present study since few or no studies attempted to review and classify research on faculty members as the subject of Turkish higher education research. However, the lack of training and socialization of scholars specialized in higher education and the absence of formal doctoral programs in higher education limit scholarly production in higher education in general and specific to faculty. The limited time frame and inclusion of studies published in Turkish journals were among the limitations of the study. We combined both academic papers and theses through criterion sampling. Previous work focused on only one topic such as doctoral dissertations (Aydın, Selvitopu \& Kaya, 2018; Forsberg \& Geschwind, 2016; Karadağ, 2018; Kıranlı Güngör \& Güngör, 2020; Melendez, 2002; Rone, 1998), or academic journals and conferences (Chen \& Hu, 2012; Hutchinson \& Lovell, 2004; Jung, 2015; Ritter, 2012; Soysal, Radmard, Kutluca, Ertepınar, Ortaç, Akdemir \& Türk, 2019; Şenay, Şengül \& Seggie, 2020; Tight, 2007).

One major finding was that the island of teaching and learning and the scholarship of discovery were located at the intersection of the research on faculty members based on Macfarlane's (2012) Higher Education Research Archipelago and Boyer's (1990) Model of Scholarship. Macfarlane (2012) has constructed a somewhat intuitive citation map including "teaching and learning, policy studies, institutional research, identity development, professional development, and philosophy". Similarly, Tight's (2012) typology includes eight distinct themes or issues within research on higher education. All of them were clustered based on the relationships in another study of Tight (2008) as the Clark Cluster covering "quality, system policy, institutional management, academic work, and knowledge" while the Ramsden Cluster encompassing "teaching and learning, course design, the student experience". Whether isolated or not, these two perspectives highlight Teaching and Learning and Policy Studies as two broader categories. 
The theme of teaching and learning was also reported to be salient among Swedish (Forsberg \& Geschwind, 2016), Korean (Jung, 2015) and, even in all non-North American higher education research settings (Tight, 2007) based on Tight's (2012) typology of themes within research on higher education. It was accompanied by the themes of the student experience, institutional management, and system policy which seemed to be the equivalents of policy studies, institutional research, and identity development. Valenzuela (2017) concluded that policy island was addressed only in 19,98\% and teaching and learning island accounted for $50 \%$ of the research in Latin America. Lovakov \& Yudkevich (2021) discovered that post-Soviet researchers had a smaller share of articles about teaching and learning issues, but a substantially larger share of policyrelated articles. Kim, Horta \& Jung (2015) analysed higher education research in international journals by researchers from China, Hong Kong, Japan, and Malaysia and determined that higher education research in Hong Kong and Malaysia was more teaching and learning-oriented while those in Japan and China were more policy-oriented. Another study by Horta \& Jung (2014) uncovered that the policy approach was dominant in Asia in the 1980s while there was a greater focus on teaching and learning in the 2000s. It is evident that higher education research focus is based on contextual clues like geography, time frame, and the development level of higher education systems. Şenay, Şengül \& Seggie (2020) concluded that Turkish higher education research was mainly concentrated on the description of current issues and improving specific undergraduate programs in teacher education and health education. Thus, it may be claimed that research on faculty members as the subject of Turkish higher education mainly focuses on practical issues through the lenses of the main islands of teaching and learning and system policy.

The scholarship of discovery and the scholarship of teaching have greater content and face validity for faculty members. The former is important for professional recognition and promotion while the latter is important for institutional prestige and motivation. In general, faculty members are more socialized into the scholarship of discovery rather than the other three domains (Austin \& McDaniels, 2006), and this provides little or no opportunity for the doctoral candidates to engage in the various forms of scholarship (Braxton, Luckey, \& Helland, 2002). Following the appointment as a faculty, the scholarship of teaching also becomes one of the main responsibilities of faculty members as it is about how students learn and the outcomes of specific interventions on the learning process (Kreber, 2001). However, the value placed upon the scholarship of teaching by colleagues may depend on promotion and tenure decisions (Ochoa, 2011). On the other hand, the scholarship of integration has been considered as "soft research" and not really scholarship at all (Barbato, 2000), and the faculty members devote less time to the scholarship of application as it is regarded to be divergent from and less significant than research or teaching (Ward, 2003). Matthews, McLinden \& Greenway (2021) discovered that the scholarship of application had the lowest frequency among the available corpus of institutional texts $(\mathrm{N}=232)$ provided by the 2017 Teaching Excellence Framework exercise in the UK. Boyer (1990) also asserted that the scholarships of integration, application, and teaching might remain undervalued if they were not evaluated fairly. The overemphasis over the scholarship of discovery and the scholarship of teaching - to some extent - is risky as they are interrelated with each other. To illustrate, Mtawa, Fongwa, \& Wangenge-Ouma (2016) claim that the scholarship of discovery is closely associated with another significant element of Boyer's model - the scholarship of integration. It can be concluded that research on faculty members as the subject of Turkish higher education research was based largely on the scholarship of discovery and the scholarship of teaching, as has been the case around the world.

We have also attempted to discuss our findings with similar contexts though the local literature did not provide us with a strong accumulation of knowledge base. Accordingly, higher education policies and issues, financing, the management, structure, and organization of higher education, pedagogy of higher education, curriculum, educational technologies, quality, internationalization and globalization, science, research, and ethics in higher education were determined to be the prevailing themes in Turkish higher education in line with the scholarship of discovery and the islands of teaching and learning, and policy studies. Besides, descriptive design, empirical studies up to 500 respondents, students and faculty members, documents and surveys, descriptive analysis, descriptive statistics, parametric tests, and Turkish as a publication medium were reported to be the common characteristics (Aydın, Selvitopu \& Kaya, 2018; Karadağ, 2018; Kıranlı Güngör \& Güngör, 2020; Soysal, Radmard, Kutluca, Ertepınar, Ortaç, Akdemir \& Türk, 2019; Şenay, Şengül \& Seggie, 2020). The descriptive nature of Turkish higher education research together with the overwhelming use of quantitative research methodology may partly be attributed to the recent emergence of the discipline as well as the research traditions of educational sciences in Turkey (Erdem, 2011; Göktaş, Hasançebi, Varışoğlu, Akçay, Bayrak, Baran \& Sözbilir, 2012; Selçuk, Kandemir, Palancı \& Dündar, 2014). In support of our findings, lack of studies on vocational \& technical education faculty (Şenay, Şengül \& Seggie, 2020) and the use of convenience sampling in quantitative studies (Aydın, Selvitopu \& Kaya, 2018; Kıranlı Güngör \& Güngör, 2020) were the issues regarding research on faculty. Data sources, data analysis procedures, and the number of participants varied based on the preferred research design.

Suggestions for future research and practical implications should be considered with the limitations of the study. Research findings revealed that there was no study of faculty academic and professional life over time. As the quantitative developments may trigger qualitative ones, the descriptive body of research focusing on faculty members as the subject of Turkish higher education research should be enriched and supported by field studies, action research, and micro-based interventions requiring a wider variety of data sources. Moreover, the preservice or in-service seminars like Preparing Future Faculty Programs in the US, recruitment, career development, and preparation for retirement (Wang, 2013) might be helpful for 
the candidates to understand and appreciate the different roles of faculty members and various types of professorial contributions in higher education. Turkish higher education researchers should also be encouraged to make connections across disciplines and use scientific outcomes to remedy social challenges. It could be suggested to establish higher education programs/departments based on interdisciplinary studies such as sociology, psychology, economics, political science, and anthropology. They may be affiliated to the faculties of education as the high producers of faculty research were located in the departments of Guidance \& Counselling, Teaching \& Learning, and Educational Administration and/ or Higher Education. These programs/departments may engage more in the study of faculty members and coordinate the efforts with the Council of Higher Education (CoHE), universities, administrators, policymakers, and practitioners. They may also have an active role in the higher education initiatives, practices, and studies to bring higher education scholars, practitioners, and theorists. Another suggestion is related to the need for improvement in the methodological training of researchers. The planning, design, sampling, and analysis procedures require major improvements. Long-term and evaluative research need to be carried out periodically. The scholarship of integration and the scholarship of application may be encouraged in faculty promotion. Faculty is at the core of higher education along with students. The departmentalized higher education structure is important for the training of the future/current faculty and new faculty socialization. However, interdisciplinary work needs to be included in the training of new faculty. Once these developments are completed, the study of faculty and other aspects of higher education as a field in Turkey may partly be 'institutionalized'.

\section{REFERENCES}

Akbulut Yıldırmış, M., \& Seggie, F. N. (2018). The development of higher education studies as an academic field: A literature review at international and national levels. Journal of Higher Education (Turkey). 8(3), 357-367.

Austin, A. E., \& McDaniels, M. (2006). Using doctoral education to prepare faculty to work within Boyer's four domains of scholarship. In J. M. Braxton (ed.), Analyzing faculty work and rewards: Using Boyer's four domains of scholarship, (pp. 51-66). New directions for institutional research, no. 129. San Francisco, Calif.: Jossey-Bass.

Aydın, A., Selvitopu, A., \& Kaya, M. (2018). A review of dissertations in the field of higher education management in Turkey. Journal of Higher Education \& Science, 8(2), 305-313.

Aypay, A. (2015). (Ed.). Türkiye'de yükseköğretim: alanı, kapsamı ve politikaları/ Higher education in Turkey: Field, scope and policies. Ankara: Pegem.

Barbato, R. (2000). Policy implications of co-operative learning on the achievement and attitudes of secondary school mathematics students (Unpublished doctoral dissertation). Fordham University, New York, NY.

Boyer, E. L. (1990). Scholarship reconsidered: Priorities of the professoriate. Princeton, N.J.: Carnegie Foundation for the Advancement of Teaching.
Braxton, J. M., Luckey, W., \& Helland, P. (2002). Institutionalizing a broader view of scholarship through Boyer's four domains. ASHE-ERIC Higher Education Report, 29(2). San Francisco: Jossey-Bass.

Calma, A., \& Davies, M. (2017). Geographies of influence: A citation network analysis of higher education 1972-2014. Scientometrics, 110(3), 1579-1599.

Chen, S. Y., \& Hu, L. F. (2012). Higher education research as a field in China: Its formation and current landscape. Higher Education Research \& Development, 31(5), 655-666.

Clement, N., Lovat, T., Holbrook, A., Kiley, M., Bourke, S., Paltridge, B., Starfield, S., Fairbairn, H., \& Mclnerney, D. (2015). Exploring doctoral examiner judgements through the lenses of Habermas and epistemic cognition. In J. Huisman, \& M. Tight (Eds.), Theory and method in higher education research (Vol. 1, pp. 213-233). Bingley, UK: Emerald Group Publishing.

Doğan, D. (2013). Problems of newly-founded universities and solution offers. Journal of Higher Education and Science, 3(2), 108-116.

Erdem, D. (2011). Türkiye'de 2005-2006 yılları arasında yayımlanan eğitim bilimleri dergilerindeki makalelerin bazı özellikler açısından incelenmesi: Betimsel bir analiz/ An analysis of the articles in educational sciences journals published in Turkey between 2005-2006 in terms of certain variables: A Descriptive analysis. Journal of Measurement and Evaluation in Education and Psychology, 2(1), 140-147.

Forsberg, E., \& Geschwind, L. (2016). The academic home of higher education research: The case of doctoral theses in Sweden. In J. Huisman and M. Tight (Eds.), Theory and method in higher education research (Vol. 2, pp. 69-93). Bingley, UK: Emerald Group Publishing.

Gök, E. \& Gümüş, S. (2015). Akademik bir alan olarak yükseköğretimin yönetimi/ Higher education administration as an academic field. In A. Aypay (Ed.). Türkiye'de yükseköğretim: alanı, kapsamı ve politikaları/ Higher education in Turkey: Field, scope and policies. Ankara: Pegem.

Göktaş, Y., Hasançebi, F., Varışoğlu, B., Akçay, A., Bayrak, N., Baran, M., \& Sözbilir, M. (2012). Trends in Educational Research in Turkey: A Content Analysis. Educational Sciences: Theory and Practice, 12(1), 455-460.

Higher Education Information Management System. (2021). Summary report on the number of faculty members. Retrieved from https://istatistik.yok.gov.tr/ on the $15^{\text {th }}$ of December, 2021.

Horta, H., \& Jung, J. (2014). Higher education research in Asia: An archipelago, two continents or merely atomization?. Higher Education, 68(1), 117-134.

Hutchinson, S. R., \& Lovell, C. D. (2004). A review of methodological characteristics of research published in key journals in higher education: Implications for graduate research training. Research in Higher Education, 45(4), 383-403.

Interuniversity Board (UAK). (2021). Bilim alanları ve anahtar kelimeler/Scientific fields and keywords/. Retrieved from https://www.uak.gov.tr/Documents/docentlik/2019-ekimdonemi/2019E_BilimAlanlariAnahtarKelimeler_250919.pdf on the $25^{\text {th }}$ of June, 2021.

Jung, J. (2015). Higher education research as a field of study in South Korea: Inward but starting to look outward. Higher Education Policy, 28(4), 495-515. 
Karadağ, N. (2018). Analysis of studies on higher education based on graduate theses. Adiyaman University Journal of Social Sciences, (29), 512-535.

Kim, Y., Horta, H., \& Jung, J. (2017). Higher education research in Hong Kong, Japan, China, and Malaysia: Exploring research community cohesion and the integration of thematic approaches. Studies in Higher Education, 42(1), 149-168.

Kıranlı Güngör, S., \& Güngör, M. (2020). Analysis of PhD theses written in the field of higher education in Turkey. Turkish Studies - Education, 15(1), 481-505.

Kreber, C. (2001). Scholarship revisited: Perspectives on the scholarship of teaching (New Directions for Teaching and Learning No. 86). San Francisco, CA: Jossey-Bass.

Küçükcan, T., \& Gür, B. S. (2009). Türkiye'de yükseköğretim: Karşılaştırmalı bir analiz/ Higher education in Turkey: $A$ comparative analysis. Ankara: Pelin Ofset.

Lovakov, A., \& Yudkevich, M. (2021). The post-Soviet publication landscape for higher education research. Higher Education, 81, 273-299.

Macfarlane, B. (2012). The higher education research archipelago. Higher Education Research \& Development, 31(1), 129-131.

Matthews, A., McLinden, M., \& Greenway, C. (2021). Rising to the pedagogical challenges of the Fourth Industrial Age in the university of the future: An integrated model of scholarship. Higher Education Pedagogies, 6(1), 1-21.

Melendez, J. (2002). Doctoral scholarship examined: Dissertation research in the field of higher education studies. Seton Hall University Dissertations and Theses (ETDs). 375.

Mtawa, N. N., Fongwa, S. N., \& Wangenge-Ouma, G. (2016). The scholarship of university-community engagement: Interrogating Boyer's model. International Journal of Educational Development, 49, 126-133.

Noui, R. (2020). Higher education between massification and quality. Higher Education Evaluation and Development, 14, 2, 93-103.

Ochoa, A. (2011). The scholarship of teaching: Yesterday, today, \& tomorrow. The Journal of the Professoriate, 6(1), 100-116.

Özen, H., \& Koçak, F. (2015). Türkiye'de öğretim elemanları/ Faculty members in Turkey. In A. Aypay (Ed.), Türkiye'de yükseköğretim: Alanı, kapsamı ve politikaları/Higher education in Turkey: Field, scope and policies. Ankara: Pegem.

Özer, M. (2011). Expansion in higher education and faculty supply in Turkey. Journal of Higher Education and Science, 1(1), 23-26.

Özoǧlu, M., Gür, B. S., \& Gümüş, S. (2016). Rapid expansion of higher education in Turkey: The challenges of recently established public universities (2006-2013). Higher Education Policy, 29(1), 21-39.

Ritter, S. E. (2012). Methodological orientation of research articles appearing in higher education journals. Marshall University Theses, Dissertations and Capstones. Paper 211.
Rone, E. C. (1998). Characteristics of higher education doctoral theses: Defrosting some frozen assets. Unpublished doctoral thesis. University of Toronto.

Rumbley, L. E., Altbach, P. G., Stanfield, D. A., Shimmi, Y., de Gayardon, A., \& Chan, R. Y. (2014). Higher education: A worldwide inventory of research centers, academic programs, and journals and publications ( $3^{\text {rd }}$ edition). Bonn: Lemmens Media.

Rumbley, L. E., Stanfield, D. A., \& de Gayardon, A. (2014). A global inventory of research, training and publication in the field of higher education: Growth, diversity, disparity. In L. E. Rumbley, P. G. Altbach, D. A. Stanfield, Y. Shimmi, A. de Gayardon, R. Chan (Eds.), Higher education: A worldwide inventory of research centers, academic programs, and journals and publications $\left(3^{\text {rd }}\right.$ edition) (pp. 23-33). Bonn: Lemmens Media.

Selçuk, Z., Palancı, M., Kandemir, M., \& Dündar, H. (2014). Tendencies of the Researches Published in Education and Science Journal: Content Analysis. Education \& Science, 39(173), 430-453.

Şenay, H. H., Şengül, M., \& Seggie, F. N. (2020). Higher education studies in Turkey: Trends and recommendations. Journal of University Research, 3(1), 1-13.

Soysal, Y., Radmard, S., Kutluca, A. Y., Ertepınar, H., Ortaç, F. R., Akdemir, Z. G., \& Türk, Z. (2019). Conceptual, phenomenal, thematic and methodological choices in the sense of higher education of Turkey. Journal of Higher Education \& Science, 9(1), 17-36.

Teichler, U. (2000) Higher education research and its institutional basis. In S. Schwarz \& U. Teichler (Eds). The Institutional Basis of Higher Education Research. Experiences and Perspectives (pp. 13-24), Dordrecht: Kluwer.

Tight, M. (2007). Bridging the divide: A comparative analysis of articles in higher education journals published inside and outside North America. Higher Education, 53(2), 235-253.

Tight, M. (2008). Higher education research as tribe, territory and/ or community: A co-citation analysis. Higher Education, 55(5), 593-605.

Tight, M. (2012). Researching higher education ( $2^{\text {nd }}$ edition). Maidenhead: Open University Press.

Valenzuela, C. G. (2017). Higher education research in Latin America: Revisiting MacFarlane's archipelago. ARC Papers Serial number 0099 submitted to International Perspectives \& Context. Retrieved from https://srhe.ac.uk/arc/17/0099.pdf on the $25^{\text {th }}$ of June, 2021.

Wang, C. (2013). Preparing Future Faculty Programs and Boyer's four domains of scholarship (Unpublished doctoral dissertation). Auburn University, Alabama, US.

Ward, K. (2003). Faculty service roles and the scholarship of engagement. ASHE-ERIC Higher Education Report, 29(5). San Francisco: Jossey-Bass. 